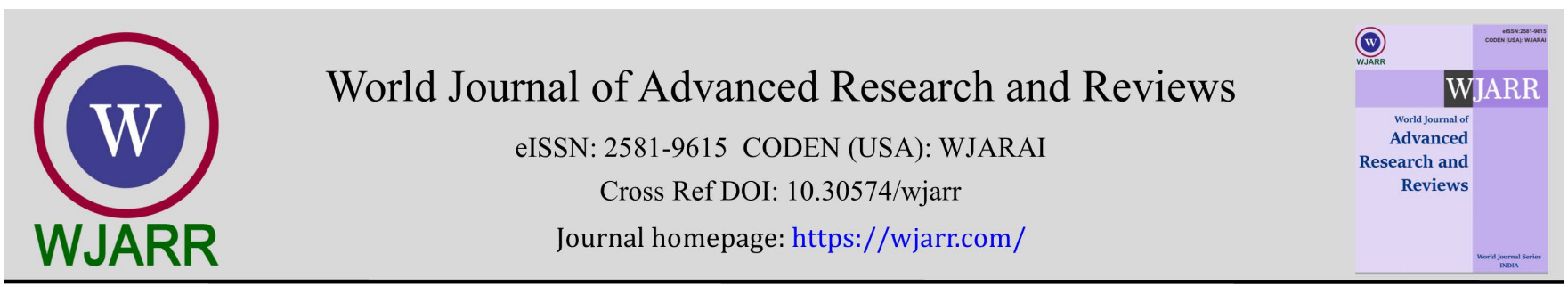

(RESEARCH ARTICLE)

\title{
Effect of fermented fish tonic on the growth and yield of Glycine max. (L)
}

\author{
Narmhikaa $\mathrm{k}^{*}$ \\ Department of Biosystems Technology, Eastern University, SriLanka.
}

World Journal of Advanced Research and Reviews, 2021, 12(03), 545-549

Publication history: Received on 17 November 2021; revised on 21 December 2021; accepted on 23 December 2021

Article DOI: https://doi.org/10.30574/wjarr.2021.12.3.0719

\begin{abstract}
Fermented fish tonic (FFT) help to provide complex arrays of macro and micro nutrients and minerals. The present study was conducted to find out the effect of Fermented fish tonic on the growth and yield of Glycine max. (L) .The experimental design was Completely Randomized Design (CRD). Five treatments were defined with five replications viz. T1: Distilled water (Control), T2: 10, T3: 20, T4: 50 and T5: 100\%. FFT. All the other management practices were followed uniformly. Growth and yield parameters were measured and analysed statistically using ANOVA test and means were compared with DMRT. Results proved that, application of $20 \%$ FFT significantly increased the plant height (9.6\%), chlorophyll content (23.02\%), number of leaves (43.66\%), leaf area (65\%), number of nodules (74.35\%), and the total yield $(75.28 \%)$ compared to the control plants. Therefore, this experiment concluds that application of $20 \%$ FFT increases the growth and yield on Glycine max. (L)
\end{abstract}

Keywords: Fermented fish tonic; Leaf area; Nodules; Plant height; Chlorophyll content

\section{Introduction}

In recent years, rise of food demand due to global overpopulation has been a burden for agriculture, which is triggering the overuse of chemical pesticides and fertilizers .Persistent usage of inorganic fertilizers makes the soil degrade seriously while destroying stable soil ecosystems. Further Environmental degradation is a major threat challenging the world, and the rampant use of chemical fertilizers contribute mostly to the deterioration of the environment through depletion of fossil fuels, generation of carbon dioxide and contamination of water resources. It leads to loss of soil fertility due to imbalanced use of fertilizers that has badly impacted agricultural productivity and caused soil degradation. Now there is a growing realization that the adoption of ecological and sustainable farming practices can only reverse the declining trend in the global productivity and environment protection.

At present, there is an increasing demand for organic fertilizers, organic farming and organic foods are becoming more popular globally due to the foremost public concern on food safety and security. organic fertilizers have become an essential component in the plant nutrient system (1) .Liquid organic fertilizers can be used to eliminate nutrient deficiency symptoms rapidly than other types of fertilizers (2). They penetrate quickly into the soil while giving access to the plant root system to absorb nutrients (3). Some studies have proved that the application of liquid organic fertilizers has the capability of increasing uptake of some macro, micronutrients and enhance the soil organic matter content compared to other types of fertilizers (4) .Organic liquid fertilizers are enriched with N, P and K can make deep replacements of inorganic fertilizers containing similar nutrients such as urea, muriate of potash etc. In general, the application of organic fertilizers increases the availability of micronutrients such as zinc, manganese, iron and copper. This is a good trend for sustainable development in agriculture and simultaneously saving biodiversity for the future (5).

\footnotetext{
${ }^{*}$ Corresponding author: Narmhikaa $\mathrm{k}$

Department of Biosystems Technology, Eastern University, SriLanka.

Copyright (C) 2021 Author(s) retain the copyright of this article. This article is published under the terms of the Creative Commons Attribution Liscense 4.0.
} 
The resourcepoor farmers have limited access to synthetic inorganic fertilizers due to high cost. Hence, nutrient availability at correct growth stages may be restricted (6). However, organic fertilizers are available and the cost is also comparatively lower than synthetic fertilizers( 3) .Organic liquid fertilizer produced from biodegradable waste can be one of the economical and effective ways of solving the garbage disposal problem in the world ( 7 ).

Soybean (Glycine max. (L)) is a leguminous vegetable of the pea family that grows in tropical, subtropical, and temperate climates. It consists of more than $36 \%$ protein, $30 \%$ carbohydrates, and excellent amounts of dietary fiber, vitamins, and minerals. It also consists of $20 \%$ oil, which makes it the most important crop for producing edible oil. Soybean being a high protein and energy crop and its productivity is often limited by the low availability of essential nutrients or imbalanced nutrition forming one of the important constraints to soybean productivity.Hence a balanced nutrients application is must to harness the productivity of the crops .Thus, the present study was designed to compare the effect of different concentration of fish tonic liuid organic fertilizers on soybean.

\section{Material and methods}

A pot experiment was conducted during the 'Maha' season. The pot experiment was arranged out in a Completely Randomised Design (CRD) with five treatments and five replications. 25 pots per treatment were used in this experiment and each pot contained two plants. This experiment was conducted using poly bags. The height of the poly bag was $35 \mathrm{~cm}$ and diameter was $20 \mathrm{~cm}$. eight small holes were made at the bottom of each poly bag to facilitate the drainage of water. The poly bags were filled with top soil and compost in the ratio of $1: 1$ and a distance of $5 \mathrm{~cm}$ was left unfilled from the top of the soil to facilitate irrigation. Glycine max. (L) Was selected for the experiment

One kilogram of fish waste was chopped and added into a plastic bucket of 15L volume to prepare the fish tonic .Small pieces of $250 \mathrm{~g}$ of jaggery and $250 \mathrm{~g}$ of raw papaya were added to the mixture and mixed well while adding clean water. Then the mixture was allowed for fermentation for two months. Fermented fish tonicFFT was applied as fertilizer by diluting with water by $1: 30(\mathrm{v} / \mathrm{v})$ ratio.

The experiment comprised of following treatments. T1: Distilled water (Control), T2: 10\% FFT, T3: 20\% FFT, T4: 50\% FFT and T5: 100\%FFT. The first application was carried out at two weeks after planting. Frequency of application was once a week. Foliar applications were done at early morning for better absorption of nutrients. All the agronomic practices were carried out in accordance with the recommendation made by the Department of Agriculture, Sri Lanka .The parameters viz. plant height, chlorophyll content (SPAD meter, Konica Minolta SPAD-502Plus), leaf area (Leaf area meter, LiCOR Inc.), total number of root nodules, biomass of leaves, stems and roots, number of seeds per pod, average weight of seeds per pod, 100 seeds weight and total yield. Data were statistically analysed with ANOVA using SAS 9.1 and means were compared using Duncan's Multiple Range Test (DMRT) at 5\% significant level.

\section{Plant height}

The results showed that application of Fermented fish tonic had significant $(\mathrm{P}<0.05)$ increase in the plant height compared to the control plants. The maximum average plant height was recorded in T3 (20\%) FFTfollowed by T2, T1, T4 while the minimum average plant height was recorded in T5 (Table 1). This might be due to the presence of macro and micro nutrients and growth promoting substances (Auxins and Cytokinins) in Fermented fish tonic. Presence of macro nutrients in foliar sprays might be increased plant height. Plant height increase also might be due to the potassium available in fish tonic. Moreover, previous study also reported that foliar application of FFT 1\% increased the plant height, number of leaves per plant and chlorophyll content to the tune of $16.5,12.6$ and $8.1 \%$ respectively over control (8)

Table 1 Effect of foliar application of FFT on plant height (cm) per plant of Glycine max.(L). Value represents mean \pm standard error of five replicates. Mean values in a column having the dissimilar letter/s indicate significant differences at $5 \%$ level of significance by DMRT

\begin{tabular}{|l|l|}
\hline Treatment & Plant height \\
\hline T1 (Control) & $36.20 \pm 1.2^{\mathrm{b}}$ \\
\hline T2: $10 \%$ & $35.48 \pm 1.2^{\mathrm{b}}$ \\
\hline T3: $20 \%$ & $41.70 \pm 1.2^{\mathrm{a}}$ \\
\hline T4: $50 \%$ & $30.64 \pm 1.2^{\mathrm{c}}$ \\
\hline T5: $100 \%$ & $30.80 \pm 1.2^{\mathrm{c}}$ \\
\hline
\end{tabular}




\subsection{Chlorophyll content of leaves per plant (SPAD)}

The results showed that application of Fermented fish tonic had a significant $(\mathrm{P}<0.05)$ increase in the chlorophyll content of leaves compared to control plants. The maximum average chlorophyll content was recorded in T3 (20\%) FFT followed by T2, T1, T4 while the minimum average plant chlorophyll content was recorded in T5 (Table 2). It clearly indicated that application of $20 \%$ FFT had significantly $(\mathrm{P}<0.05)$ increased average chlorophyll content compared to control plant.

This might be due to higher nutrient availability of Fermented fish tonic and better uptake of nutrients resulted in increased LAI and plant height with better photosynthesis activity and accumulation Fish fertilizers help to provide complex arrays of nutrients and minerals as proven by trial done in poor soil that were lacking many nutrients and minerals. Fish offal fertilizer provides plenty of phosphorous and organic nitrogen (9).

Table 2 Effect of foliar application of FFT on chlorophyll content per plant of Glycine max. (L) .Value represents mean \pm standard error of five replicates. Mean values in a column having the dissimilar letter/s indicate significant differences at $5 \%$ level of significance by DMRT

\begin{tabular}{|l|l|}
\hline Treatment & Plant height \\
\hline T1 (Control) & $37.20 \pm 2.2 \mathrm{~b}$ \\
\hline T2: $10 \%$ & $44.48 \pm 1.2 \mathrm{~b}$ \\
\hline T3: $20 \%$ & $50.70 \pm 1.2 \mathrm{a}$ \\
\hline T4: $50 \%$ & $36.42 \pm 1.2 \mathrm{~b}$ \\
\hline T5: $100 \%$ & $36.42 \pm 1.2 \mathrm{~b}$ \\
\hline
\end{tabular}

\subsection{Leaf area}

Table 3 Effect of foliar application of FFT on Leaf area per plant of Glycine max.(L) . Value represents mean \pm standard error of five replicates. Mean values in a column having the dissimilar letter/s indicate significant differences at $5 \%$ level of significance by DMRT

\begin{tabular}{|l|c|}
\hline Treatment & Leaf area $(\mathbf{c m} 2)$ \\
\hline T1 (Control) & $585.65 \pm 0.87^{\mathrm{b}}$ \\
\hline T2 $(10 \%)$ & $622.32 \pm 0.24^{\mathrm{b}}$ \\
\hline T3 $(20 \%)$ & $1331.44 \pm 0.94^{\mathrm{a}}$ \\
\hline T4 $(50 \%)$ & $469.35 \pm 1.08^{\mathrm{b}}$ \\
\hline T5 $(100 \%)$ & $462.39 \pm 0.77^{\mathrm{b}}$ \\
\hline
\end{tabular}

Data showed that application of Fermented fish tonic had a significant increase $(\mathrm{P}<0.05)$ in leaf area when compared to control plants (T1). The maximum leaf area was recorded in T3 followed by T2, T1. The minimum leaf area was recorded in T4 and T5 (Table 3). The present experiment showed that foliar application of FFT with $20 \%$ concentration increased the average leaf area by $45.40 \%$, compared with T1 (control). It might be due to the presence of Zn and Fe in FFT. It was clearly indicated that presence of micro and macronutrient in foliar extracts, increases the leaf area per plant (10).

\subsection{Total number of root nodules}

Application of FFT significantly $(\mathrm{P}<0.05)$ increased the total number of root nodules when compared with the control (T1). The maximum number of root nodules was recorded in T3 (20\%) followed by T2 (10\%), T1 (control), T4 (50\%) and T5 (100\%) (Table 4). This result proved that 20\% FFT gave the best performance. Fish fertilizers help to provide complex arrays of nutrients and minerals as proven by trial done in poor soil that were lacking many nutrients and minerals. Fish offal fertilizer provides plenty of phosphorous and organic nitrogen(9). 
Table 4 Effect of foliar application of FFT on total number of root nodules and weight of nodules per plant of Glycine max.(L) . Value represents mean \pm standard error of five replicates. Mean values in a column having the dissimilar letter/s indicate significant differences at $5 \%$ level of significance by DMRT

\begin{tabular}{|l|c|}
\hline Treatment & Total number of root nodules \\
\hline T1 (Control) & $37 \pm 1.24 \mathrm{~b}$ \\
\hline T2 $(10 \%)$ & $47 \pm 0.84 \mathrm{~b}$ \\
\hline T3 $(20 \%)$ & $58 \pm 1.04 \mathrm{a}$ \\
\hline T4 $(50 \%)$ & $32 \pm 0.92 \mathrm{~b}$ \\
\hline T5 $(100 \%)$ & $32 \pm 1.02 \mathrm{~b}$ \\
\hline
\end{tabular}

\subsection{Total yield per plant}

The maximum average total yield was recorded in T3 followed by T1 and the minimum in T5 (100\%) (Table 5). It might be due to the presence of macro and micronutrients in FFT. Further Phosphorus available in FFT promotes root development, root growth and stimulates flowering. These effects ultimately enhance growth and yield of plant by initiating a vigorous plant growth. It might be due to the nitrogen in the fish fertilizer encourages lots of leaves and branches, which help support the large root system and bountiful crop. Studies done on peas, radishes, tomatoes, corn, straw berry, lettuce, soybeans, and peppers indicated that fish offal's fertilizer promote plant growth and retard senescence (10). Further Fish liquid fertilizer is a good soil conditioner and is great to use in vegetable plots since it will help in root development (9).

Table 5 Effects of foliar application of FFT on total yield per plant per plant of Glycine max.(L). Value represents mean \pm standard error of five replicates. Mean values in a column having the dissimilar letter/s indicate significant differences at $5 \%$ level of significance by DMRT

\begin{tabular}{|l|c|}
\hline Treatment & Total yield per plant (g) \\
\hline $\mathrm{T} 1($ Control) & $2.52 \pm 1.05 \mathrm{~b}$ \\
\hline $\mathrm{T} 2(10 \%)$ & $2.27 \pm 1.60 \mathrm{~b}$ \\
\hline $\mathrm{T} 3(20 \%)$ & $7.17 \pm 0.97 \mathrm{a}$ \\
\hline $\mathrm{T} 4(50 \%)$ & $1.50 \pm 0.39 \mathrm{~b}$ \\
\hline $\mathrm{T} 5(100 \%)$ & $1.06 \pm 0.43 \mathrm{~b}$ \\
\hline
\end{tabular}

\section{Conclusion}

It could be concluded that foliar spray of Fermented fish tonic significantly influenced the various physiological parameters and yield of Glycine max. (L). among five treatments T3 Fermented fish tonic shows the best results compared with the other treatments. Therefore, this experiment concluded that application of $20 \%$ Fermented fish tonic increased the growth and yield on Glycine max. (L).

\section{Compliance with ethical standards}

\section{Acknowledgments}

I acknowledge the efforts of all those who contributed toward making this work a success.

\section{References}

[1] Ahmad AA, Radovich TJK, Nguyen HV, Uyeda J, Arakaki A, Cadby J, Paull R, Sugano J and Teves G. Use of Organic Fertilizers to Enhance Soil Fertility, Plant Growth and Yield in a Tropical Environment. In: Larramendy ML and Soloneski S (ed.) Organic Fertilizers- From Basic Concepts to Applied Outcomes. InTech, Croatia. 2016. 
[2] Fageria NK, Filho MPB, Moreira A and Guimarães CM. Foliar 67 Tropical Agricultural Research \& Extension 23 (3 \& 4): 2020 fertilization of crop plants. Journal of Plant Nutrition. 2009; 32(6): 1044-1064.

[3] Wang Y, Zhu Y, Zhang S and Wang Y. What could promote farmers to replace chemical fertilizers with organic fertilizers. Journal of Cleaner Production. 2018; 199: 882-890.

[4] Browaldh M. Influence of organic and inorganic fertilizers on common bean (Phaseolus vulgaris L.) grown in a P fixing Mollic Andosol. Biological Agriculture and Horticulture. 1992; 9(1): 87- 104.

[5] Bengtsson J, Ahnström J and Weibull AC. The effects of organic agriculture on biodiversity and abundance: A meta-analysis. Journal of Appl. Ecol. 2005; 42(2): 261-269.

[6] 6 Odhiambo JJO and Magandini VN. An assessment of the use of mineral and organic fertilizers by smallholder farmers in Vhembe district, Limpopo province, South Africa. African Journal of Agricultural Research. 2008; 3(5): $357-362$.

[7] 7 Le NP, Nguyen TTP and Zhu D. Understanding the stakeholders' involvement in utilizing municipal solid waste in agriculture through composting: A case study of Hanoi, Vietnam. Sustainability. 2018; 10: 23-14.

[8] 8Ramesh T, Rathika S, Murugan A, Soniya RR, Mohanta KK, Prabharani B. Foliar spray of fish amino acid as liquid organic manure on the growth and yield of Amaranthus. Chemical Science Review and Letters. 2020; 9: 511-515

[9] 9Irshad I, Javed SD. Effects of different dosages of nursery fertilizes in the control of root rot of Okra and Mung bean. Pak. J. Bot. 2006; 38(1): 217-223.

[10] 10Aung LH, Flick GJ, Bluss GR, Aycock HS, Keefer RF, Singh R., Brandon DM, Griffin JL, Hovermale CH, Stutte CA. The Growth responses of crop plants to fish soluble nutrients fertilization. Virginia polytechnic institute and Univeristy, Blacksbarg, Virginia, Bulletin. 1984; 80: 84-9. 